\title{
Comment on "Novel Glutamatergic Modulators for the Treatment of Mood Disorders: Current Status"
}

\author{
Marco Pappagallo ${ }^{1} \cdot$ Charles E. Inturrisi ${ }^{1} \cdot$ Paolo L. Manfredi ${ }^{1}$
}

Accepted: 17 December 2021 / Published online: 11 January 2022

(c) The Author(s) 2022

We truly appreciated the thorough article by Henter and colleagues published in the May 2021 issue of CNS Drugs titled "Novel Glutamatergic Modulators for the Treatment of Mood Disorders: Current Status" [1].

In regard to dextromethadone, the authors state: "as an enantiomer of the opioid methadone, concerns persist about its abuse and dependence potential" [1]. Chiral configuration is known to impart opioid activity to molecules: as a rule, for chiral molecules, only one of the two enantiomers is opioid active. In regard to methadone, dextromethadone is the opioid-inactive enantiomer and levomethadone is the opioidactive enantiomer [2-7]. According to a recent US Drug Enforcement Administration statement on racemic methadone, dextromethadone "lacks significant respiratory depressant action and abuse liability" [8]. Dextromethorphan, another molecule discussed by the authors as a potentially rapid-acting antidepressant [1], is the dextroisomer of a full opioid agonist drug, racemethorphan, and, like dextromethadone, it does not have clinically meaningful opioid agonist activity, in contrast with the levoisomer, levomethorphan.

We agree with the authors about the need to fully characterize the abuse potential of novel antidepressants, including dextromethadone. However, we hope that overconcern about abuse will not unjustifiably bias the development of potentially safe and highly effective medications that may impact on disease mechanisms of mood disorders and bring meaningful and lasting changes in the quality of life of suffering patients.

This comment refers to the article available online at https://doi. org/10.1007/s40263-021-00816-x.

An author's reply to this comment is available at https://doi.org/10. 1007/s40263-021-00892-z.

Paolo L. Manfredi

pmanfredi@relmada.com

1 Relmada Therapeutics, Inc., 2222 Ponce de Leon Blvd. Floor

3, Coral Gables, FL 33134, USA

\section{Declarations}

Conflicts of interest Marco Pappagallo, Charles Inturrisi and Paolo Manfredi are paid consultants for Relmada Therapeutics. Charles Inturrisi and Paolo Manfredi are inventors on patents and patent applications related to dextromethadone.

Funding This Letter is funded by Relmada Therapeutics.

Author contributions Marco Pappagallo, Charles Inturrisi and Paolo Manfredi prepared the Letter, approved the final version for publication and agree to be accountable for its contents.

Availability of data and material Not applicable.

Code availability Not applicable.

Consent to participate Not applicable.

Consent for publication Not applicable.

Ethics approval Not applicable.

Open Access This article is licensed under a Creative Commons Attribution-NonCommercial 4.0 International License, which permits any non-commercial use, sharing, adaptation, distribution and reproduction in any medium or format, as long as you give appropriate credit to the original author(s) and the source, provide a link to the Creative Commons licence, and indicate if changes were made. The images or other third party material in this article are included in the article's Creative Commons licence, unless indicated otherwise in a credit line to the material. If material is not included in the article's Creative Commons licence and your intended use is not permitted by statutory regulation or exceeds the permitted use, you will need to obtain permission directly from the copyright holder. To view a copy of this licence, visit $\mathrm{http} / / /$ creativecommons.org/licenses/by-nc/4.0/.

\section{References}

1. Henter ID, Park LT, Zarate CA Jr. Novel glutamatergic modulators for the treatment of mood disorders: current status. CNS Drugs. 2021;35(5):527-43. https://doi.org/10.1007/s40263-021-00816-X (Epub 2021 Apr 26). 
2. Eddy NB, Halbach H, Braenden OJ. Synthetic substances with morphine-like effect: clinical experience; potency, side-effects, addiction liability. Bull World Health Organ. 1957;17:569-863.

3. Gorman AL, Elliott KJ, Inturrisi CE. The d- and 1-isomers of methadone bind to the non-competitive site on the N-methyl-Daspartate (NMDA) receptor in rat forebrain and spinal cord. Neurosci Lett. 1997;223:5-8.

4. Isbell $\mathrm{H}$, Eisenman AJ. The addiction liability of some drugs of the methadone series. J Pharmacol Exp Ther. 1948;93:305-13.

5. Lemberg K, Kontinen VK, Viljakka K, et al. Morphine, oxycodone, methadone and its enantiomers in different models of nociception in the rat. Anesth Analg. 2006;102:1768-74.
6. Pasternak GW, Pan YX. Mu opioids and their receptors: evolution of a concept. Pharmacol Rev. 2013;65:1257-317.

7. Soyka M, Zingg C. Feasibility and safety of transfer from racemic methadone to $(\mathrm{R})$-methadone in primary care: clinical results from an open study. World J Biol Psychiatry. 2009;10:217-24.

8. US Drug Enforcement Administration: Drug and chemical information section: methadone. Springfield, VA, US Drug Enforcement Administration, Diversion, Control Division. 2020. https:// www.deadiversion.usdoj.gov/drug_chem_info/methadone/metha done.pdf. 